\title{
LARVAE AND ADULTS OF ASCAROPS SP. (NEMATODA: SPIROCERCIDAE) COLLECTED FROM THE STOMACH OF MAXOMYS WHITEHEADI (RODENTIA: MURINAE) IN KALIMANTAN, INDONESIA
}

\author{
Hideo Hasegawa ${ }^{1}$ and Kartika Dewi ${ }^{2 *}$ \\ ${ }^{1}$ Department of Biology, Faculty of Medicine, Oita University, Hasama, Yufu, Oita 879-5593, Japan \\ ${ }^{2}$ Museum Zoologicum Bogoriense, Research Center for Biology, Indonesian Institute of Sciences (LIPI), \\ J1. Raya Jakarta-Bogor Km. 46, Cibinong, Bogor 16911, Indonesia \\ *Corresponding author: kartika_mzb@yahoo.co.id
}

Received: 15 March 2021; Accepted: 26 June 2021

\begin{abstract}
Third-stage larvae and adults of spiruroid nematodes were found from the stomach wall and stomach lumen, respectively, of Maxomys whiteheadi (Rodentia: Murinae) captured in Bukit Soeharto, Kalimantan, Indonesia. Close observation using light microscope and scanning electron microscope (SEM) revealed that it belongs to the genus Ascarops (Nematoda: Spirocercidae), possibly to Ascarops strongylina (Rudolphi, 1819). It is presumed that this species is parasitic in wild boars, Sus barbatus, in the forest of Kalimantan, and utilizes the murine as a paratenic host, in which it usually remains as third larval stage but can occasionally develop to adult stage.
\end{abstract}

Keywords: Ascarops, Kalimantan, Maxomys whiteheadi, Nematoda

\begin{abstract}
ABSTRAK
Larva tahap ketiga dan dewasa dari nematoda spirurida ditemukan berturut-turut dari dinding dan lumen lambung Maxomys whiteheadi (Rodentia: Murinae) yang ditangkap di Bukit Soeharto, Kalimantan, Indonesia. Berdasarkan hasil pengamatan menggunakan mikroskop cahaya dan mikroskop elektron mengungkapkan bahwa nematoda tersebut masuk dalam genus Ascarops (Nematoda: Spirocercidae), kemungkinan adalah Ascarops strongylina (Rudolphi, 1819). Diduga spesies tersebut merupakan parasit pada babi liar, Sus barbatus, yang terdapat di hutan Kalimantan, dan menggunakan tikus sebagai inang perantara.
\end{abstract}

Kata kunci: Ascarops, Kalimantan, Maxomys whiteheadi, Nematoda

\section{INTRODUCTION}

Ascarops strongylina (Rudolphi, 1819) (Nematoda: Spirocercidae) is a cosmopolitan species usually parasitic in pigs and wild boars (Shmitova, 1964). It utilizes insects such as dung beetles as intermediate hosts and various vertebrates as paratenic hosts (Ono, 1933; Alicata, 1935; Shmitova, 1964). Rats and mice have been known to play a role as paratenic hosts (Ono, 1933; Varma et al., 1976). Meanwhile, Hasegawa et al. (1994) first found adults of this nematode in the stomach of Rattus rattus on Lan $\mathrm{Yu}$, a remote island of Taiwan. By checking nematode specimens collected from murine rodents captured in Kalimantan, Indonesia, some adult worms belonging to the genus Ascarops were found from Maxomys whiteheadi along with the third-stage larvae encysted in the stomach wall. We conducted detailed observation using light microscope and scanning electron microscope to elucidate the precise morphology of the worms. 


\section{MATERIALS AND METHODS}

The host murines were captured in Bukit Soeharto Preserved Forest, Kalimantan, Indonesia, in August 1993. Methods of trapping and examination were given in Hasegawa and Syafruddin (1997). The viscera were excised and fixed in $70 \%$ ethanol and then transferred to $5 \%$ formalin. The alimentary canal was incised and the contents were washed with running water on a fine sieve with aperture size of $75 \mu \mathrm{m}$. Then, the residues on the sieve were transferred to a petri dish with the proper amount of water, and examined for nematodes under a stereomicroscope. The alimentary canal wall was also examined for the presence of nematode cysts. Cysts were incised using fine needles to recover larva inside. Collected nematodes were rinsed in $70 \%$ ethanol, cleared in glycerol ethanol solution by evaporating ethanol, and mounted in 50\% glycerol for observation under a light microscope Olympus BX50 equipped with a differential interference contrast apparatus. Some worms were examined using a JEOL JSM-IT 200 scanning electron microscopy (SEM) at an accelerating voltage of $5 \mathrm{kV}$. Before observed, nematodes were fixed in glutaraldehyde and cacodylate buffer, dehydrated in alcohol concentration series beginning from $70 \%$ to absolute, vacuumdried using TAITEC VC-96N, at least for 30 minutes, mounted on specimen stub, and then coated with gold at 5-8 $\mathrm{m} \AA$ for $5 \mathrm{~min}$. Voucher specimens were deposited in the Museum Zoologicum Bogoriense (MZB).

\section{RESULTS}

Four males and 1 female and 1 fragmented female of adult stage and one fourth-stage larva of Ascarops were recovered from the stomach of $M$. whiteheadi. Prevalence was 35\% (6 out of 17) with intensity of 1 to 2 (mean 1.3). Third-stage larvae were also found forming round cyst of about $0.5 \mathrm{~mm}$ in diameter, in various organs, mostly the stomach wall, but also in small intestine serosa and mesentery, with prevalence of 53\% (9 out of 17) (Fig. 1).

\section{Morphological description}

\section{Ascarops sp.}

(Nematoda: Spirurida: Spiruroidea: Spirocercidae: Ascaropsinae)

Third-stage larvae (10 individuals): Forming round cysts of about $0.5 \mathrm{~mm}$ in diameter (Fig. 1). Body slender, tapering to both extremities (Figs. 2, 3, 6). Cuticle with fine transverse striations. Lateral alae absent. Mouth elongated dorso-ventrally, hexagonal, surrounded by lateral projections and dorsal and ventral elevations; lateral shields trapezoid, each with amphidial pore at upper base; four large cephalic papillae present (Fig. 4). Pharynx thick- 
walled; esophagus divided into short anterior muscular portion and long posterior glandular portion. Nerve ring near posterior end of muscular esophagus and excretory pore at level of junction of muscular and glandular portions (Fig. 2). Deirids small, spike-like, positioned asymmetrically: left deirid much anterior to right deirid (Fig. 5). Tail conical with terminal round tubercle (Figs. 3, 6). Phasmidial pore minute, in posterior half of tail (Fig. 6). Primordial gonad ellipsoidal, located ventral to intestine (Fig. 7). Measurements are given in Table 1 comparing with previous reports.

Fourth-stage larva (1 individual): Still within cuticle of third-stage (Figs. 8, 9). General morphology similar to third-stage larva except pharynx with faint spiral markings (Fig. 8) and string-like gonad. Deirids hardly to be observed. Tail conical, with round terminal tubercle (Fig. 9). Measurements are given in Table 1 comparing with previous data.

Adults: Body tapered anteriorly (Fig. 10). Cuticle with fine transverse striations (Fig. 11). Lateral alae indistinct. Mouth with lateral pseudolabia each with three elevations; four submedian cephalic papillae and two amphids present (Fig. 11). Pharynx with spiraled thickenings (Figs. 11, 12). Nerve ring slightly anterior to junction between muscular and glandular portions of esophagus; excretory pore slightly posterior to nerve ring. Deirids spikelike, asymmetrically positioned: left deirid anterior to right deirid.

Male (3 worms): With asymmetrical caudal ala; verrucose markings well developed; cloacal aperture encircled by hemicircular disc with serrated margin; caudal papillae 4 pairs precloacal and 6 pairs postcloacal: 1st pair of postcloacal papillae inside of hemicircular disc; 2nd pair large, situated laterally; 3rd to 5th pairs minute, lined at midlevel of tail; 6th pair near tail end; phasmidial pore between 5th and 6th postcloacal papillae (Figs. 14 - 16). Spicules unequal, left spicule slender, much longer than stout right spicule (Fig. 13). Measurements are given in Table 2 comparing with previous data.

Female (2 worms): Vulva at ventral elevation, seen only in fragmented female (Fig. 17). Tail conical. Eggs not formed. Measurements are given in Table 3 comparing with previous data.

Host: Maxomys whiteheadi (Rodentia: Muridae: Murinae)

Site of infection: Stomach (adult worms and fourth-stage larva); stomach wall (thirdstage larvae).

Locality: Bukit Soeharto, Kalimantan, Indonesia.

Date of collection: August 1993.

Voucher specimens: MZBNa 835. 
Remarks: The morphology of the third-stage larvae is identical to that of A. strongylina described from the intermediate hosts, dung beetles, by Alicata (1935) and Shmitova (1959). Although the body size was somewhat larger than those in the previous reports (Table 1), this difference might be due to the fact that the present larvae had somewhat grown in the paratenic mammalian host. The fourth-stage larva obtained had a body size comparable to the third-stage, much smaller than that described by Shmitova (1959) (Table 1). It was still in the cuticle of the previous larval stage and had characteristic spiral thickenings in the pharynx and elongated primordial gonad, indicating a molting stage from the third- to the fourth-stage (Shmitova, 1959).

The present adult worms were much smaller than $A$. strongylina recorded from $R$. rattus of Lan Yu, Taiwan (Hasegawa et al. 1994; Tables 2, 3). Meanwhile, two of the adult males $(\# 1,2)$ obtained had nearly comparable body size with the immature adult males recovered from a pig 26 days of experimental infection (Shmitova, 1959) (Table 2). The pharynx with clear spiral thickenings, asymmetrical caudal alae, the hemicircular disc with serrated margin guarding the cloacal aperture and the caudal papillae arrangement are identical with those of A. strongylina (Shmitova, 1964). The remaining male (\#3) was much smaller but possessed characteristic hemicircular disc encircling cloacal aperture and developed unequal spicules (Table 2, Fig. 13), suggesting it was just after the final molt. The adult female \#1 was first surmised to be a fourth-stage larva because no vulva was found. However, it was assigned to the adult stage as it had spiral thickenings much clearer than those observed in the present fourth-stage larva. 

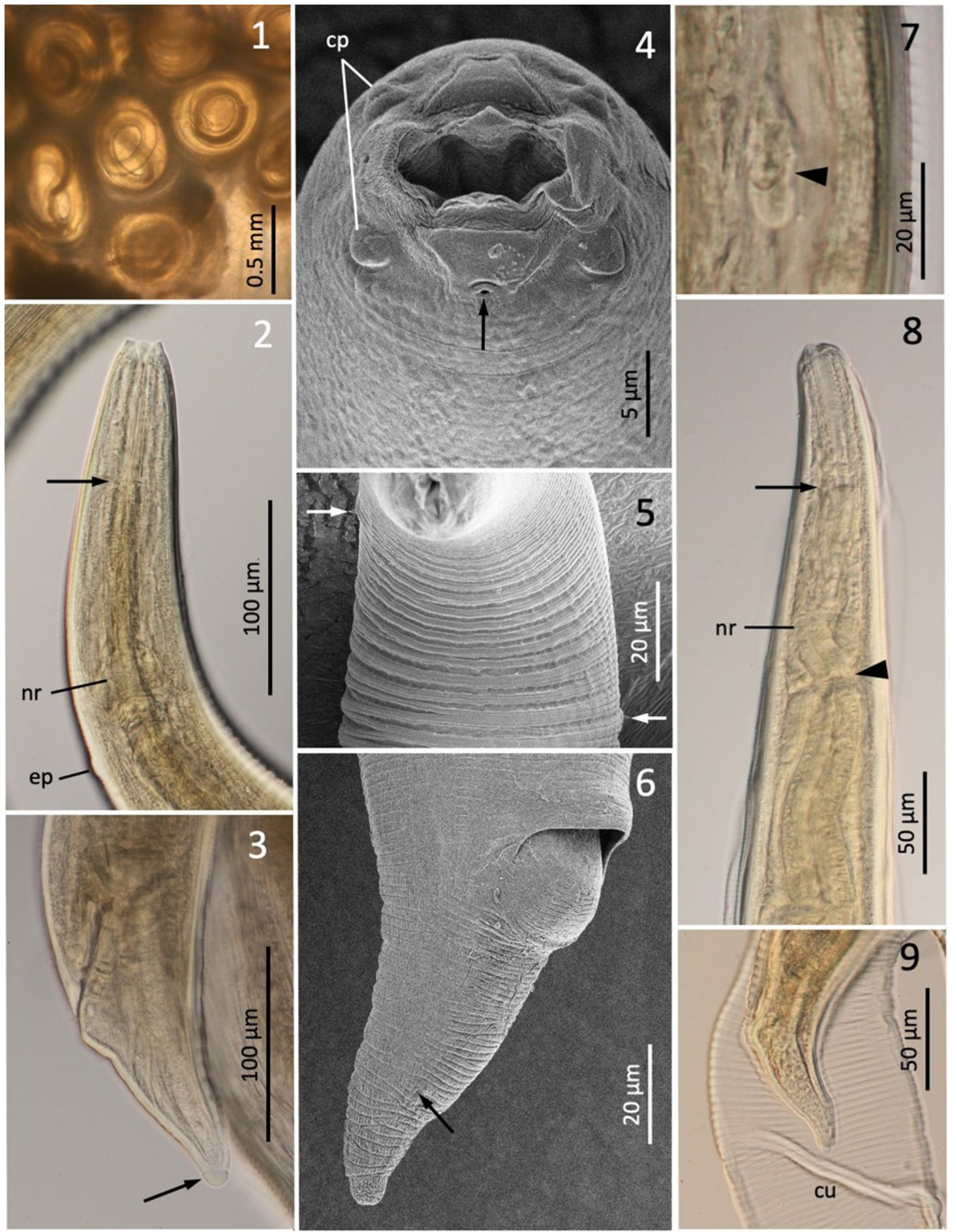

Figs. 1-7. Third-stage larva of A scarops sp. found from Maxomys whiteheadi in Kalimantan, Indonesia. 1. Larvae encysted in the stomach wall of $M$. whiteheadi. 2. Anterior end, left lateral view. Arrow showing junction between pharynx and muscular portion of esophagus. 3. Posterior end, left lateral view. Arrow showing round tubercle at tail tip. 4 - 6. SEM images of cephalic apex, apical view, showing amphidial pore (arrow) and papillae arrangement (4), anterior end, dorsal view, showing asymmetrically positioned deirids (arrows) (5), and tail showing minute phasmidial pore (arrow) (6). 7. Midbody showing gentail primoudium (arrow). Figs. 8 and 9. Molting larva of A scarops sp. recovered from the stomach contents of Maxomys whiteheadi in Kalimantan, Indonesia. 8. Anterior end, left lateral view, showing pharynx with vague spiraled markings. Arrow and arrowhead indicating junction between pharynx and muscular esophagus and junction between muscular and glandular portions of esophagus, respectively. 9. Posterior end, left lateral view, showing detached cuticle.

Abbreviations: cp. cephalic papillae; cu. cuticle; ep. excretory pore; nr. nerve ring. 

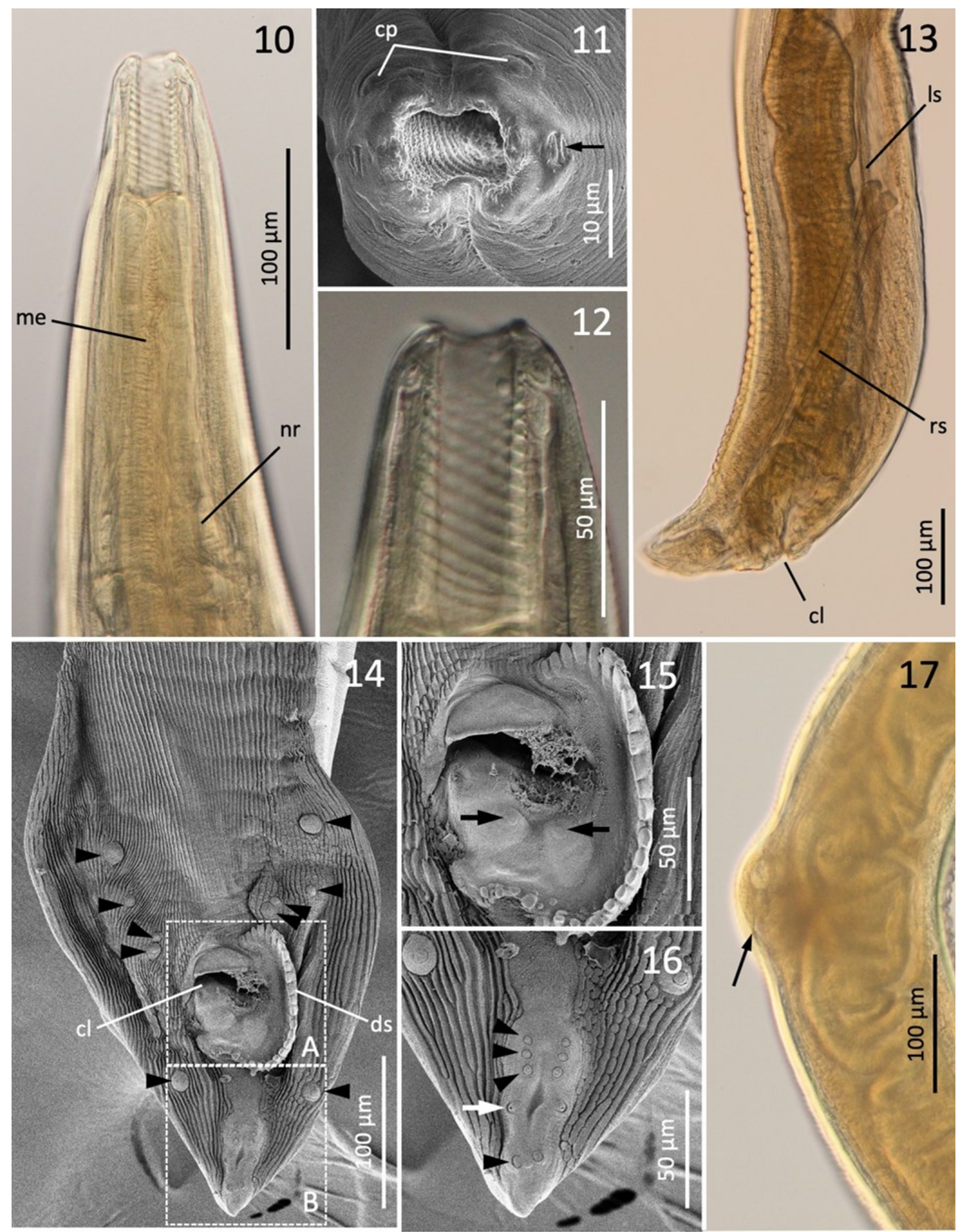

Figs. 10 - 16. Male adults of A scarops sp. found from Maxomys whiteheadi in Kalimantan, Indonesia. 10. Anterior end, lateral view; 11. Cephalic apex, apical view, showing amphid (arrow) and papillae arrangement. 12. Pharynx showing spiraled markings, lateral view. 13. Posterior body of immature worm, right lateral view, showing spicules. 14. Posterior end with asymmetrical caudal alae, ventral view, showing hemicircular disc with serrated margin around cloacal aperture, arrangement of caudal papillae (arrowheads). 15. Enlarged view of boxed area A of Fig. 14, showing two papillae just posterior to cloacal aperture (arrows). 16. Enlarged view of boxed area B of Fig. 14, showing minute papillae near tail end (arrowheads) and phasmids (white arrow). 17. Vulval region of immature female, lateral view, showing elevated condition. Arrow indicating vulva.

Abbreviations: cl. cloacal aperture; cp. cephalic papillae; ds. hemicircular disc; ls. left spicule; me. muscular portion of esophagus; r. nerve ring; rs. right spicule. 


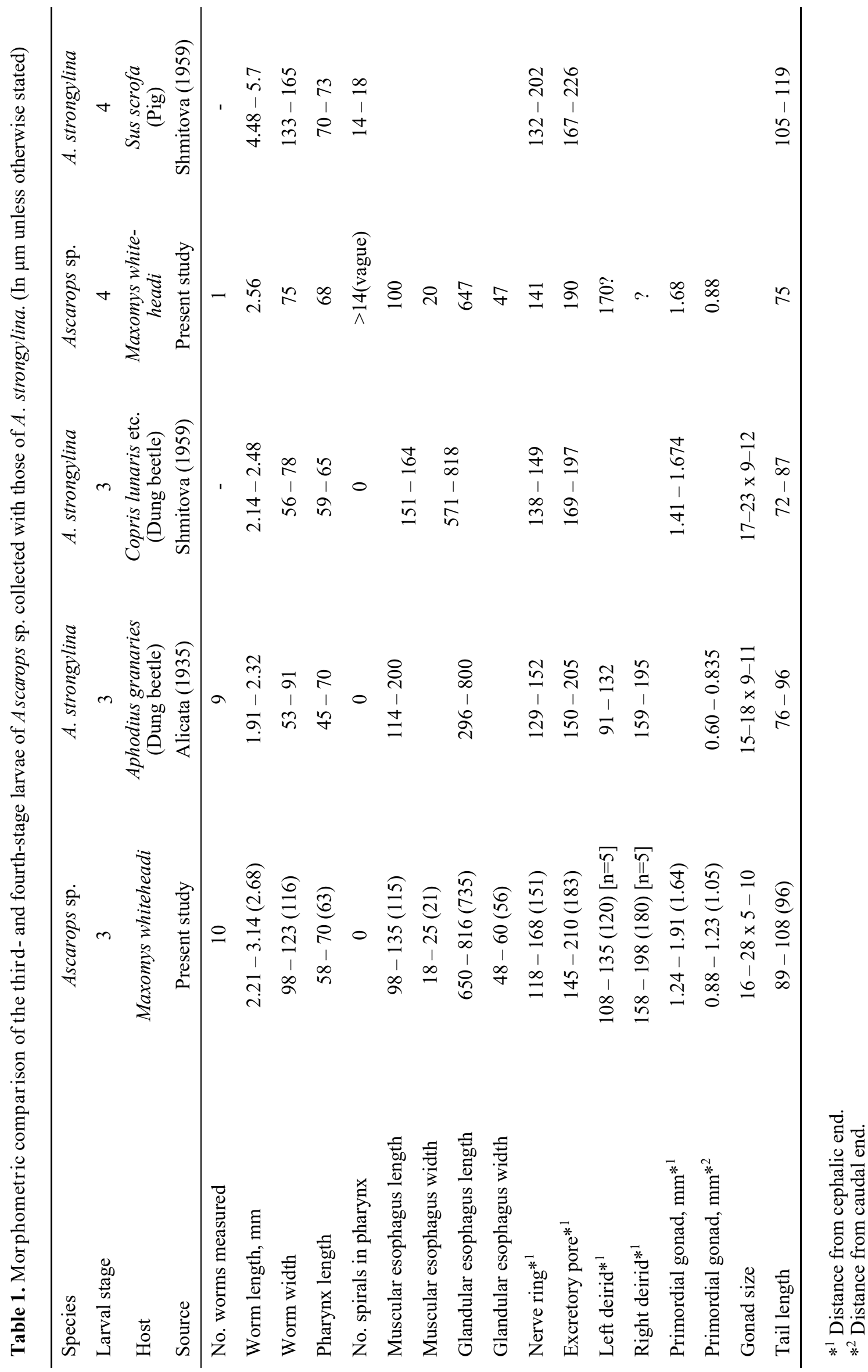




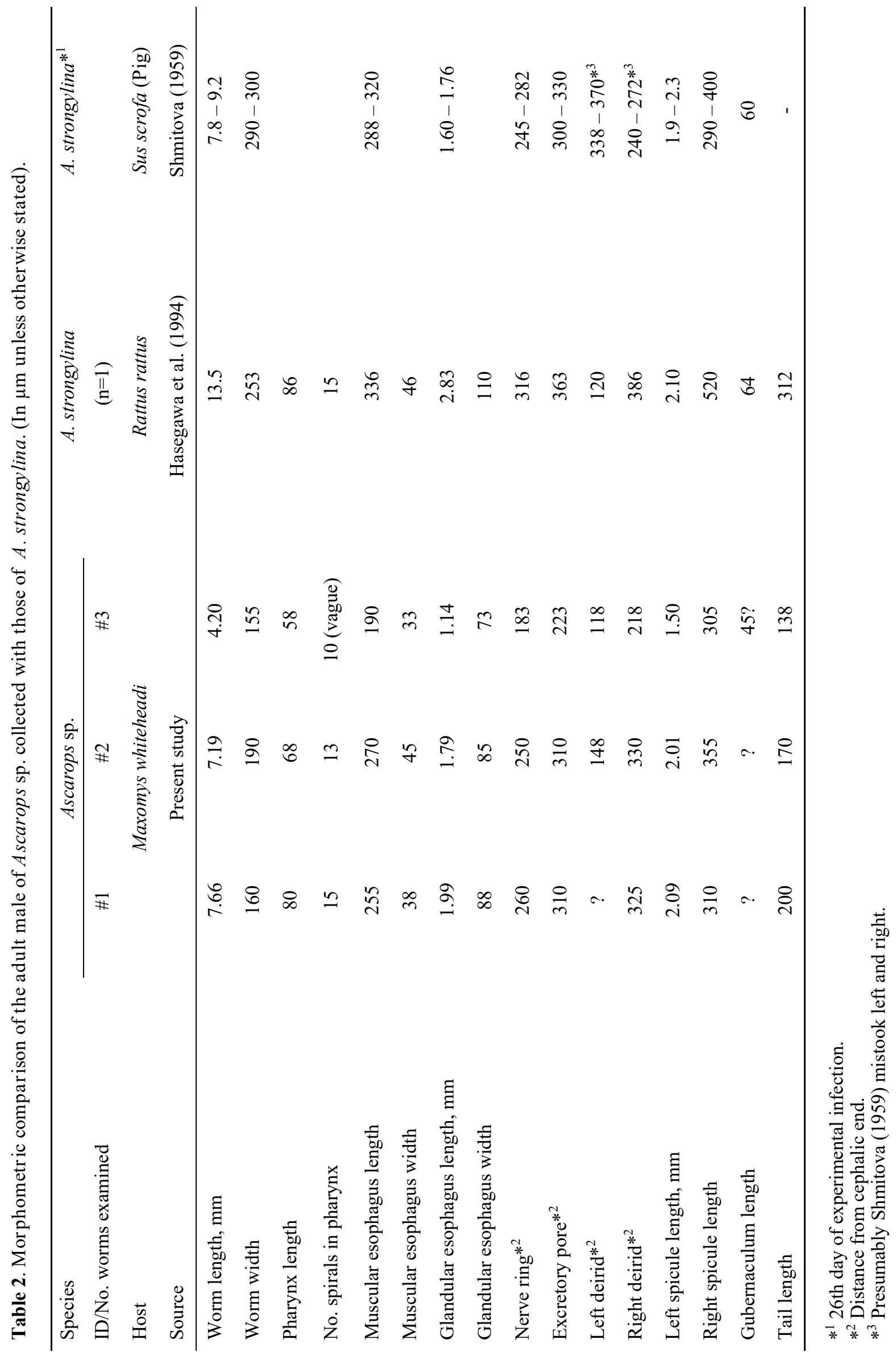


Hasegawa \& Dewi: Larvae and adults of A scarops ....

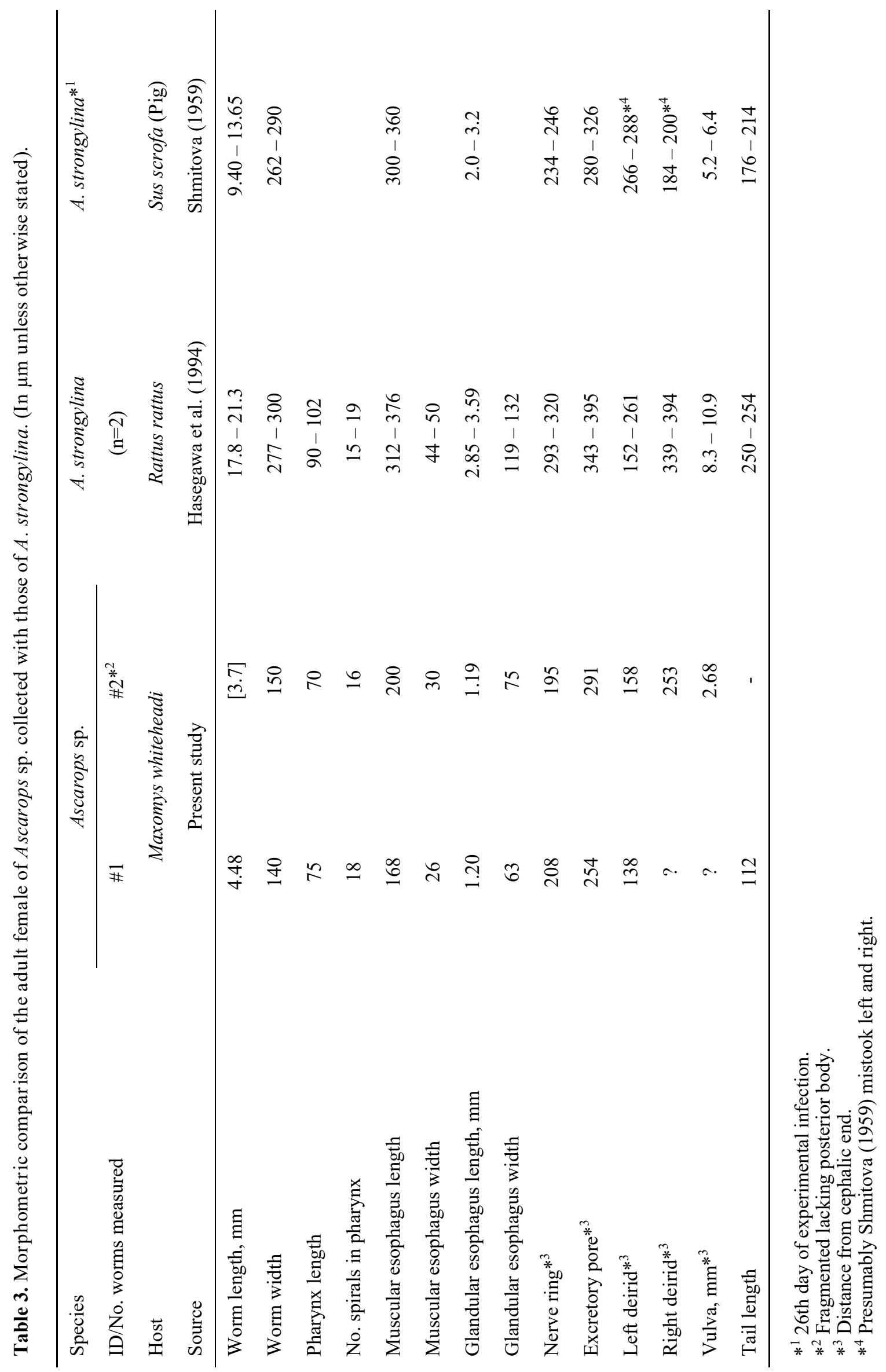




\section{DISCUSSION}

Adults of the species of the genus Ascarops are parasitic in pigs, wild boars, rodents, and insectivores, but rarely in birds and reptiles (Yamaguti, 1961; Yokohata \& Abe, 1989). Seven species are known currently in this genus, namely A. strongylina Rudolphi, 1819 (type species), A. africana (Sandground, 1933), A. dentata Linstow, 1904, A. mogera Yokohata \& Abe, 1989, A. psittaculai Sood \& Kalia, 1975, A. scaptochiri Yin \& Zhang, 1981 and A. talpa Huber, Schmidt \& Kuntz, 1983 (Yamaguti, 1961; Yin \& Zhang, 1981; Huber et al., 1983; Yokohata \& Abe, 1989). Among them, A. strongylina, A. africana, A. dentata and $A$. psittaculai possess pericloacal disc with serrated margin in male adults (Sandground 1933; Shmitova, 1964; Skrjabin et al., 1967; Sood \& Kalia, 1975). A scarops strongylina and $A$. dentata are parasitic in pigs and wild boars usually, A. africana was described from African rats, Mastomys and Rhabdomys, and A. psittaculai was established as an avian nematode (Sandground, 1933; Skrjabin et al., 1967; Sood \& Kalia, 1975). Ascarops dentata and $A$. africana have large, stout bodies in full grown adults, being readily distinguished from A. strongylina and A. psittaculai (Sandground, 1933; Skrjabin et al., 1967; Sood \& Kalia, 1975). The pericloacal disc of $A$. dentata completely encircles the cloacal aperture, while those in the remaining three species are hemicircular as in the present male adults. Ascarops africana was first distinguished from the other congeners by having a pair of large papillae just posterior to the cloacal aperture (Sandground, 1933). However, Ascarops species have a common caudal papillae pattern of so-called 'Spirurid type' (Chabaud \& Petter, 1961). Sood \& Kalia (1975) did not give a discrimination argument for $A$. psittaculai from other nominal congeners, but it resembled closely $A$. strongylina.

The presence of Ascarops in accidental hosts has been reported. Sandground (1933) found A. africana in a snake, Boaeden lineatus, and surmised that it acquired the worms by ingesting true host murid. Prod'hon (1967) also reported A. africana from a mongoose, Herpestes ichneumon, and considered that this accidental host had eaten the infected rodent, though his worms had only transverse, not spiral, thickenings of the pharynx wall. Besides those cases acquired by ingestion of infected definitive hosts, the third-stage larva has been known to develop to adult stage in accidental hosts. By experimental infection, the third-stage larvae of $A$. strongylina successfully developed to adult worms in rabbits (Ono, 1933; Alicata \& McIntosh, 1933; Gupta, 1969). Surprisingly, A scarops adults have been recorded from avian hosts: Jairajpuri \& Siddiqi (1971) found one adult male of A scarops sp. under the gizzard lining of a carnivorous bird, Accipiter badius, in India; Sood \& Kalia (1975) found 11 adults of $A$. psittaculai from the intestine of a parakeet, Psittacula krameria, 
of India; Webster \& Speckman (1977) also demonstrated many adult worms of $A$. strongylina from the proventriculus and gizzard of a cockatoo, Cacatua galerita galerita, in Canada. The authors suggested that species of A scarops are not strictly host-specific and can establish in hosts belonging to different groups of vertebrates.

Besides A. africana, some records have been made on adult Ascarops from murids. Hasegawa et al. (1994) identified the worms from $R$. rattus of Lan Yu, Taiwan, as $A$. strongylina. Ganzorig et al. (1999) also recorded A. strongylina from a cricetid, Myospalax psilurus, in Mongolia, but this identification was doubtful because their males had much longer right spicule than the left one. Unidentified A scarops adults were also collected from a cricetid, Neotoma micropus, of Texas (Charles et al., 2012). We surmise that the present worms, both larvae and adults, belong to one species, possibly A. strongylina. Presumably, the definitive host is the bearded pig, Sus barbatus, that is widely distributed in Borneo/ Kalimantan (Luskin \& Ke, 2017). Maxomys whiteheadi plays a role as paratenic host, but the third-stage larvae may occasionally develop to adult stage in it. The absence of gravid females suggests that this rat is not a suitable final host.

As shown above, Ascarops species have wide host ranges and the morphology has not been fully understood yet. Some of them are surmised to be synonymous with each other. DNA sequence analysis may be especially helpful for strict identification of the species, and for elucidation of relationship of larva with adult stages found in a host. Unfortunately, no DNA sequence data are registered in the GenBank at the present time.

\section{ACKNOWLEDGMENTS}

Sincere thanks are rendered to Dr. M. Asakawa, Rakuno Gakuen University, Dr. R. Nakao, Hokkaido University, and Dr. T. Iwaki, Meguro Parasitological Museum, for their kindness in searching the voucher specimens of Ascarops from M. psilurus and/or in providing us copies of relevant literature. This study was partly supported by the research grants from the Ministry of Education, Science and Culture, Japanese Government (No. 03041065) (for H.H.) and DIPA Research Center for Biology-LIPI 2019 under project "Fauna Jawa" (for K.D.).

\section{REFERENCES}

Alicata, J.E. 1935. Early Developmental Stages of Nematodes Occurring in Swine. Technical Bulletin No. 489. United States Department of Agriculture, Washington D.C.: 96pp.

Alicata, J.E. \& McIntosh, A. 1933. A scarops strongylina (Rudolphi, 1819), the correct name for Arduenna strongylina (Rudolphi, 1819) Railliet and Henry, 1911, and Ascarops minuta Beneden, 1873. Journal of Parasitology, 20(1): 62. 
Chabaud, A.J. \& Petter, A.J. 1961. Remarques sur l'evolution des papilles cloacales chez les nématodes phasmidiens parasites de vertebrés. Parasitologia, 3(1, 2): 51-70.

Charles, R.A., Kjos, S., Ellis, A.E., Dubey, J.P., Shock, B.C. \& Yabsley, M.J. 2012. Parasites and vector-borne pathogens of southern plains woodrats (Neotoma micropus) from southern Texas. Parasitology Research, 110(5): 1855-1862. https://doi.org/10.1007/s00436-011-2710-z

Ganzorig, S., Batsaikhan, N., Samiya, R., Morishima, Y., Oku, Y. \& Kamiya, M. 1999. A second record of adult Ascarops strongylina (Rudolphi, 1819) (Nematoda: Spirocercidae) in a rodent host. Journal of Parasitology, 85(2): 283-285.

Gupta, V.P. 1969. Pond-snake and ground squirrel as paratenic hosts of Ascarops strongylina. Current Science, (22): 548-549.

Hasegawa, H., Kobayashi, J. \& Otsuru, M. 1994. Helminth parasites collected from Rattus rattus on Lanyu, Taiwan. Journal of the Helminthological Society of Washington, 61(1): 95-102.

Hasegawa, H. \& Syafruddin. 1997. Maxomystrongylus yasumai gen. and sp. n. (Nematoda: Trichostrongylina: Heligmonellidae) collected from murid rodents of Kalimantan, Indonesia. Journal of the Helminthological Society of Washington, 64(2): 263-268.

Huber, P.M., Schmidt, G.D. \& Kuntz, R.E. 1983. A scarops talpa sp. n. (Nematoda: Spirocercidae) from the Formosan mole, Talpa micrura insularis, in Taiwan. Journal of Parasitology, 69(4): 761763.

Jairajpuri, D. S. \& Siddiqi, A.H. 1971. On some nematodes of birds from India. Part II. Spiruridae and Hedruridae. The Research Bulletin of the Meguro Parasitological Museum, (5): 21-26.

Luskin, M. S. \& Ke, A. 2017. Chapter 18. Bearded pig, Sus barbatus (Müller, 1838). In: Melletti, M. \& Meijaard, E. (eds.) Ecology, Conservation and Management of Wild Pigs and Peccaries. Cambridge (U.K.): Cambridge University Press: 175-184.

Ono, S. 1933. Studies on the life-history of Spiruridae in Manchuria. I. Journal of the Japan Veterinary Medical Association, 12(3): 165-184. (In Japanese)

Prod'hon, J. 1967. Etude de trois Nématodes Spirurides d'Angola. N.o 71 Das Publicações Culturais da Companhia de Diamantes de Angola, (Lisboa): 45-60.

Sandground, J.H. 1933. No. 6. Reports on the scientific results of an expedition to the southwestern highland of Tanganyika Territory. VI. Parasitic nematodes from East Africa and Southern Rhodesia. Bulletin of the Museum of Comparative Zoology Harvard Collection Cambridge, 75(6): 263-293.

Shmitova, G.Y. 1959. Development of Ascarops strongylina in its definitive host. Helminthologia, 1 (1-4): 209-219. (In Russian)

Shmitova, G.Y. 1964. Study of the ontogenic development of Ascarops strongylina. Trudy Gel'intologicheskoi Laboratorii, 14: 288-301. (In Russian)

Skrjabin, K.I., Sobolev, A.A. \& Ivashkin, V.M. 1967. Essentials of Nematology 19. Spirurata of Animals and Man and the Diseases Caused by Them. Part 5. Supplement (In Russian). Moscow: Izdatel'stvo Nauka: 240 pp. (In Russian)

Sood, M.L. \& Kalia, R. 1975. Records of two nematode parasites uncommon in birds. Acta Parasitologica Polonica, 23(31): 361-365.

Varma, S., Malik, P.D. \& Lal, S.S. 1976. White mice as reservoirs of swine stomach worm Ascarops strongylina. Haryana Agricultural University Journal of Research, 6(3-4): 246-247.

Yamaguti, S. 1961. Systema Helminthum III. Nematodes. 2 Vols. New York: Interscience: 1261 pp.

Webster, W.A. \& Speckman, G. 1977. The description of a gubernaculum in Ascarops strongylina (Rudolphi, 1819) (Spiruroidea) and a note on the recovery of this nematode from a bird. Canadian Journal of Zoology, 55(2): 310-313.

Yin, W.Z. \& Zhang, N.X. 1981. On some parasitic nematodes from rodents and insectivore in Peking, China. A cta Zootaxonomica Sinica, 6(1): 16-21. (In Chinese)

Yokohata, Y. \& Abe, H. 1989. Two new spirurid nematodes in Japanese moles, Mogera spp. Japanese Journal of Parasitology, 38(2): 92-99. 